\title{
L Antigen Family Member 3
}

National Cancer Institute

\section{Source}

National Cancer Institute. L Antigen Family Member 3. NCI Thesaurus. Code C105656.

L antigen family member 3 (143 aa, $\sim 15 \mathrm{kDa}$ ) is encoded by the human LAGE3 gene. This protein has no known function. 